\title{
Andean blueberry (Vaccinium floribundum) bread: physicochemical properties and bioaccessibility of antioxidants
}

\author{
Michelle GUIJARRO-FUERTES ${ }^{1}$, Maria Jose ANDRADE-CUVI ${ }^{1}$, Juan BRAVO-VÁSQUEZ ${ }^{1}$, \\ Luis RAMOS-GUERRERO ${ }^{1}$, Maria Gabriela VERNAZA ${ }^{2 *}$
}

\begin{abstract}
The Andean Blueberry (Vaccinium floribundum) is a fruit with a recognized antioxidant capacity. Its consumption is limited to typical food in the Andean Ecuadorian zones. In this study, the effect of the addition of Andean blueberry (AB) pulp on loaf bread quality was determined. The specific volume was affected by the low fermentation rate due to the acidic $\mathrm{pH}$ of the fruit. The texture profile measurement demonstrated a product with harder consistency, due to the low number and circularity of the alveoli. Higher air retention in the crumb was also found. Simulated Gastrointestinal conditions directly affected the antioxidant capacity of the $\mathrm{AB}$, producing a reduction of $96.9 \%$. On the other hand, the $\mathrm{AB}$ bread initially presented a value of $37 \mu \mathrm{M}$ Trolox/g and, after the digestion process, a value of $10.6 \mu \mathrm{M}$ Trolox/g, corresponding to a percentage of bioaccessibility of $28.6 \%$. The global results indicate that the gluten network would protect the antioxidant compounds of the AB. It was possible to develop bread with healthier properties, due to the high antioxidant content of the $\mathrm{AB}$.
\end{abstract}

Keywords: anthocyanins; baking process; in vitro digestion; antioxidant capacity.

Practical Application: The addition of Andean Blueberry pulp increases the antioxidant capacity in foods.

\section{Introduction}

The Andean blueberry is part of the family Ericaceae, generally found in the mountainous areas of northwestern South America, from which about 4,500 species with different variables of this family are derived. It belongs to the genus Vaccinium, and the species floribundum is found in Ecuador (Vasco et al., 2008). This fruit is known for its nutraceutical functions due to its high antioxidant capacity and its potential for agricultural production and processing (Coba Santamaría et al., 2012).

Antioxidant capacity can be defined as the characteristic of certain molecules to have activity against oxidizing agents; this feature represents the ability of the antioxidant compounds to decrease oxidant species by donating a hydrogen or electron (Quintanar \& Calderón, 2009). Oxidation usually affects biological substrates and is initiated by the action of reactive species such as free radicals and other species which, without being free radicals, may induce the oxidation process (Pokorn et al., 2001). Free radicals are species that have an unpaired electron in their outermost orbital (Gutiérrez et al., 2007).

It has been determined that the antioxidant capacity of Andean blueberries is around 1,200 mg equivalents of Trolox/100 g tissue (Vasco et al., 2008). The compounds that are outlined predominantly within this system of antioxidants in Andean blueberries are the anthocyanins, which are evidenced by the bluish black color of the fruit. As for other polyphenolic compounds, the presence of gallic acid, derivatives of vanillic acid and hydroxybenzoic acid, proanthocyanidins, quercetin and derivatives of chlorogenic acid have been determined. On the other hand, the high content of antioxidant compounds in mature fruits has been reported as consequent oxidative stress, increasing phenol levels in advanced development stages (Coba Santamaría et al., 2012).

Even though the content of some antioxidant compounds, such as anthocyanins, is reduced during storage, higher losses occur during processing (Chaovanalikit \& Wrolstad, 2004). Temperature is the main factor in the destabilization of molecular structure. The higher the temperature of the process, the greater the destruction of the anthocyanins, since hydrolyzation of the 3 -glucoside structure occurs, which is a protective component of the anthocyanin structure (Gaviria et al., 2011).

In recent years, new food products have been developed with plant components, such as anthocyanins extracted from black rice (Sui et al., 2015), and used as active ingredients in processed food matrices. However, it has been demonstrated that its digestibility could be improved and the bioaccessible fraction could increase in baked products (Rupasinghe et al., 2008). It is therefore important to exploit the use of raw materials rich in antioxidant compounds, such as Andean blueberries, for the formulation of functional foods. On the other hand, the "bioavailability of food in organisms" is defined as the efficiency of a particular compound or property (such as antioxidant capacity) to be used systematically through the normal metabolic pathway and to be expressed as a percentage of intake. It is influenced

${ }^{1}$ Centro de Investigación de Alimentos - CIAL, Facultad de Ciencias de la Ingeniería e Industrias, Universidad Tecnológica Equinoccial - UTE, Quito, Ecuador ${ }^{2}$ Departamento de Ingeniería en Alimentos, Colegio de Ciencias e Ingeniería - El Politécnico, Universidad San Francisco de Quito - USFQ, Quito, Ecuador

*Corresponding author: mgvernaza@usfq.edu.ec 
by various factors, either from the nutrient matrix or from the host organism (Aggett, 2010). Determination of bioavailability includes three processes: bioaccessibility (release of the compound from its matrix into the intestinal lumen), intestinal transport (transport through the intestinal epithelium into the body) and metabolism (degradation of the compounds in the liver) (Versantvoort et al., 2004). This model of study can be used as a basis for the development of technical standards and food optimization to improve established nutritional recommendations (Jadán et al., 2013). The aim was to determine the effect of the addition of Andean blueberry (AB) pulp on the physicochemical properties and on the bioaccessibility of antioxidants in bread.

\section{Materials and methods}

The Andean blueberry (AB) (Vaccinum floribundum Kunt) was harvested in the area of Ilinizas (northern highlands of Ecuador, province of Pichincha $0^{\circ} 40^{\prime}$ S, $78^{\circ} 45^{\prime} \mathrm{W}$ ) with commercial maturity corresponding to: $\mathrm{pH}=2.7$; soluble solids $=9.9 \%$; total acidity $=1.6 \%$ citric acid; $\mathrm{L}^{*}=28.0 ; \mathrm{a}^{*}=1.3$ and $\left.\mathrm{b}^{*}=-1.7\right)$. Wheat flour was used (Planiplus, Moderna Alimentos) with the following characterization: $11 \%$ protein, $65.5 \%$ water absorption, $5 \mathrm{~min}$ stability, $36 \%$ wet gluten, $10 \%$ dry gluten and 280 s Falling Number).

\subsection{Andean blueberry bread preparation}

Loaf bread samples were prepared based on a no-time bread-making process. The formulation of bread was: wheat flour (100\%), vegetable fat (6\%), fresh yeast (8\%), white sugar $(20 \%)$, water $(63 \%)$ and salt (1\%). AB was added as fruit pulp in a proportion of $50 \%$ mixed with the remaining $13 \%$ water of the water requirement in the formulation. To obtain the bread, the ingredients were first blended for 6 min until reaching optimum development of the gluten. Subsequently, $220 \mathrm{~g}$ pieces were formed, followed by $60 \mathrm{~min}$ of proofing at $40{ }^{\circ} \mathrm{C}$ with $85 \%$ relative humidity in a chamber proofer. After fermentation, the dough was baked at $200^{\circ} \mathrm{C}$ for $20 \mathrm{~min}$. The $\mathrm{AB}$ bread was stored at room temperature for $24 \mathrm{~h}$ for further analysis. Simultaneously, a control bread, without the fruit pulp, was made following the same steps described above.

\subsection{Characterization of breads}

The obtained breads were characterized by $\mathrm{pH}$ according to the AACCI Method 02-52.01 (Association of Cereal Chemists International, 2010), water activity (Aw) of crumbs using a Hygrolab C1 electrical water activity analyzer (Hygrolab C1, Rotronic, Bassersdorf, Switzerland) at room temperature and the titratable acidity following the AACCI Method 02-31.01 (Association of Cereal Chemists International, 2010). The crumb moisture of the fresh breads was determined according to the AACCI Method 44-15.02 (Association of Cereal Chemists International, 2010). Three replicates were made in each measurement. The specific volume was determined following the AACCI method 10-05.05 (Association of Cereal Chemists International, 2010). Twelve measurements of each sample were made. The determination of color of the crust and crumbs was determined after 24 hours of baking, using the rectangular space Hunter $L^{*}, a^{*}$ and $b^{*} ; 30$ measurements were taken using a Chroma Meter CR-400 Konica Minolta colorimeter. In addition, the browning index (BI) were determined according to Correa (2012).

For the texture profile analysis, the methodology of Bourne (2002) was applied in a TA-XT2i (Stable Micro Systems) texturometer. The $\mathrm{AB}$ bread was compressed to up to $40 \%$ of the original height by means of a SP25 cylindrical probe at a speed of $0.5 \mathrm{~mm} / \mathrm{s}$. The texture parameters evaluated were: maximum strength or hardness $(\mathrm{N})$, consistency $\left(\mathrm{N}^{\star} \mathrm{s}\right)$, cohesiveness, elasticity and resilience. The parameters were calculated using Texture Expert software for Windows. Trials were performed in triplicate.

The analysis of the crumbs' alveoli was carried out according to the method described by Correa (2012). The analyzed characteristics of the crumbs were: number of alveoli, alveolar area (mean and mode), air fraction (relation between alveolar area and total area), circularity and alveolar perimeter. The circularity was determined as the quotient between the area of the alveolus and the area of a circle with the same perimeter (Equation 1), being a character of dimensionless form related to the degree of compaction. Circularity takes values between 0 and 1 .

Circularity $=4 * \pi *\left(\right.$ area $/$ perimeter $\left.^{2}\right)$

\subsection{Determination of the antioxidant capacity}

The antioxidant capacity was determined using the ABTS $\bullet+$ radical, following the methodology described by Re et al. (1999). For the determination of the antioxidant capacity, extracts of the fluids of each stage, ethanolic extract of fresh fruit and breaded product were diluted until finding an inhibition of 20 to $80 \%$ in comparison to the absorbance of the target. The synthetic antioxidant of the Trolox reference was tested at a concentration of $0.5 \mathrm{mM}$ in ethanol under the same conditions above. The results were expressed as $\mu \mathrm{mol}$ Trolox $/ \mathrm{g}$ tissue (wet basis). The trial was performed in triplicate.

\subsection{In vitro digestion}

Fresh $\mathrm{AB}$ and bread samples were digested in vitro according to a modified protocol developed by Gião et al. (2012) for the mastication and duodenal stages and by Aura (2005) for the gastrical stage. At each stage of the gastrointestinal tract, samples of $7 \mathrm{~mL}$ were taken and kept frozen at $-20^{\circ} \mathrm{C}$ for further determination of antioxidant capacity. The aliquots obtained in each phase were processed as an ethanolic extract, centrifuged at $4000 \mathrm{rpm}$ during $30 \mathrm{~min}$ at $4^{\circ} \mathrm{C}$ and then filtered. As for the duodenal stage, another aliquot was taken which was dialyzed using a $25 \mathrm{~mm}$ wide (flat) dialysis membrane with a pore size of $12000 \mathrm{Da}$. In this process, the residue and the soluble fraction in the organism were separated, determining that the bioaccessible fraction is the one transported through the dialysis membrane (Torres, 2011).

\subsection{Statistical analysis}

All analyses were performed in at least triplicate and the results as mean \pm standard deviation. One-way analysis of variance (ANOVA) was followed by Tukye's test $(\mathrm{p}<0.05)$ Infostat 
software (version 2010, Argentina) to evaluate the differences among samples.

\section{Results and discussion}

\subsection{Determination of $\mathrm{pH}$ and specific volume}

The $\mathrm{pH}$ of the dough decreased after the leavening stage in both the control bread and the $\mathrm{AB}$ bread. The decrease in $\mathrm{pH}$ at this stage is important since it indicates that the yeast was not inactivated by adding $\mathrm{AB}$ pulp in the formulation. However, the fermentation rate was affected; the $\mathrm{pH}$ reduction was 21 and $2 \%$ for the control bread and $\mathrm{AB}$ bread, respectively. The $\mathrm{pH}$ range for the optimal yeast activity is 4.5-6.0 (Cauvain, 2015). Therefore, the addition of $\mathrm{AB}$ pulp, as well as the presence of lactic acid bacteria (LAB) like suggest Rollán et al. (2010), reduced the initial $\mathrm{pH}$ of the dough, which could affect the final volume of the bread due to the low production of $\mathrm{CO}_{2}$ generated in the fermentation of sugars through the action of the yeast (Delcour \& Hoseney, 2010).

The control bread presented a higher specific volume than the $\mathrm{AB}$ bread, with a difference of $36 \%$ (Table 1) due to the substitution of $50 \%$ of water by pulp of the fruit in the AB bread. The most favored $\mathrm{pH}$ range for yeast activity is 4.5-6.0. When water is used for bread formulations, $\mathrm{pH}$ values of bread dough are generally in the region of 5.5, and therefore, the expansion of dough during proof is largely controlled by the rate at which the carbon dioxide gas is generated within the dough (Cauvain, 2015).

However, when pulp fruit is used instead of water, the $\mathrm{pH}$ would decrease due to the acidity of the fruit and therefore, the rate of fermentation would be also lower. The lower volume of the $\mathrm{AB}$ bread was due to the lower initial $\mathrm{pH}$ being near the lower limit of the optimum $\mathrm{pH}$ of the yeast, which is 4.5 (Cauvain, 2015). The greater fermentative development is due to the maximum $\mathrm{CO}_{2}$ production within the dough, which is produced in dough with $\mathrm{pH}$ values between 5 and 6 , being the most precise 5.4 to 5.8 (Sánchez, 2002).

Table 1. Physical-chemical characterization of Andean blueberry bread and Control bread.

\begin{tabular}{|c|c|c|c|}
\hline \multicolumn{2}{|c|}{ Parameter } & Control bread & $\begin{array}{c}\text { Andean blueberry } \\
\text { bread }\end{array}$ \\
\hline \multicolumn{2}{|c|}{$\mathrm{pH}$ fresh dough } & $5.6 \pm 0.1^{\mathrm{a}}$ & $4.6 \pm 0.0^{\mathrm{b}}$ \\
\hline \multicolumn{2}{|c|}{ fermented dough } & $4.4 \pm 0.1^{\mathrm{b}}$ & $4.5 \pm 0.0^{\mathrm{a}}$ \\
\hline \multicolumn{2}{|c|}{ Bread } & $5.9 \pm 0.0^{\mathrm{a}}$ & $4.7 \pm 0.0^{\mathrm{b}}$ \\
\hline \multicolumn{2}{|c|}{ Specific volume $(\mathrm{cm} 3 / \mathrm{g})$} & $4.4 \pm 0.1^{\mathrm{a}}$ & $2.8 \pm 0.1^{\mathrm{b}}$ \\
\hline \multirow[t]{4}{*}{ Crust Color } & $\mathrm{L}^{*}$ & $70.6 \pm 2.1^{\mathrm{a}}$ & $44.9 \pm 6.2^{b}$ \\
\hline & $a^{*}$ & $14.7 \pm 1.1^{\mathrm{a}}$ & $10.9 \pm 0.5^{b}$ \\
\hline & $b^{*}$ & $41.3 \pm 0.8^{\mathrm{a}}$ & $13.3 \pm 2.5^{b}$ \\
\hline & BI & $98.1 \pm 5.8^{\mathrm{a}}$ & $52.2 \pm 7.5^{b}$ \\
\hline \multirow[t]{3}{*}{ Crumb Color } & $L^{*}$ & $92.1 \pm 2.0^{\mathrm{a}}$ & $33.7 \pm 1.2^{b}$ \\
\hline & $a^{*}$ & $-1.8 \pm 0.4^{b}$ & $11.6 \pm 0.5^{\mathrm{a}}$ \\
\hline & $b^{*}$ & $18.8 \pm 0.5^{\mathrm{a}}$ & $4.3 \pm 0.3^{b}$ \\
\hline \multicolumn{2}{|c|}{ Crumb Moisture } & $32.6 \pm 1.1^{\mathrm{b}}$ & $35.3 \pm 1.6^{\mathrm{a}}$ \\
\hline \multicolumn{2}{|c|}{ Aw bread } & $0.92 \pm 0.01^{\mathrm{b}}$ & $0.90 \pm 0.01^{\mathrm{a}}$ \\
\hline
\end{tabular}

Averages with different letters in the same line show significant differences between the samples using the Tukey test $(\mathrm{p}<0.05)$.
In addition, the gluten matrix would have been affected by the substitution of water by the $\mathrm{AB}$ pulp, which would give an approximate concentration of $7 \mathrm{~g}$ of total fiber per each $100 \mathrm{~g}$, where $6 \mathrm{~g}$ corresponds to insoluble fiber. Silva et al. (2011) indicated that technologically, the presence of fiber (its insoluble part in greater percentage) generates interferences in the mechanical formation causing discontinuity in the gluten network; therefore, the capacity to maintain the gas produced in the fermentation is diminished.

\subsection{Crust and crumb color}

A useful quality parameter of breaded products is color determination, which together with the texture and flavor generated could be the cause of acceptance or rejection of a product (Bedolla et al., 2004). During the processing of AB bread, the violet-bluish color of the fruit (Arteaga Dalgo et al., 2012) contributes colorations in the violet range to the dough and bread (Figure 1). The addition of $\mathrm{AB}$ pulp in the formulation produced significant changes in the crust and crumb color parameters. The control bread presented higher values of $\mathrm{L}^{*}, \mathrm{a}^{*}, \mathrm{~b}^{*}$ and $\mathrm{BI}$ than the AB bread (Table 1). The crust of the $\mathrm{AB}$ bread had $36.4 \%$ lower luminosity than the control bread. While browning results in the reduction of the $\mathrm{L}^{\star}$ parameter (Conesa et al., 2012), this difference would be related to the absorption of light in the structure of the crust (Sui et al., 2015), as well as anthocyanins degradation, which is a non-enzymatic browning reaction (Sui et al., 2015)

Regarding the $\mathrm{a}^{*}$ and $\mathrm{b}^{*}$ values, different behavior was observed between crust and crumb. The change in $\mathrm{a}^{\star}$ value indicates variation towards the red-blue color tone (Westland, 2012), which was observed mainly in the $A B$ bread crumb, due to pigments like anthocyanins that provide the purple-blue color to the fruit (Arteaga Dalgo et al., 2012). The b* value indicates the tonality of yellow (Westland, 2012). Values of 41.3 and 18.8, for crust and crumb respectively, were found in the control bread, while the $A B$ bread presented values of 13.4 and 4.3 (crust and crumb), perceiving an effect of the addition of $A B$ pulp in the superficial and internal color of the bread.

Both the control and $\mathrm{AB}$ bread produced a Maillard reaction, where melanoidin and hydroxymethylfurfural (Cauvain, 2015) caused a brown color to the crust, which is shown by the value of $\mathrm{BI}$ indicating the purity of the color produced by the compounds synthesized in the non-enzymatic browning reactions. BI values of 98.1 were found for the control bread. Similar values were reported by Correa (2012) for wheat flour bread with modified celluloses, while the $\mathrm{AB}$ bread presented a value of 52.2. This difference is due to the fact that the $A B$ pulp produces an alteration of the characteristic color of bread that is developed by a Maillard reaction during baking.

\subsection{Crumb moisture}

Water is an important element in bread processing, because it affects both the characteristics of the dough and bread quality. The $\mathrm{AB}$ bread presented $7.5 \%$ higher moisture than the control bread. The $A B$ pulp would have an influence on hydration and dough formation, dough consistency, temperature control of 
Cross-section

Upper view

Alveolated crumb analysis image

\section{Control Bread}
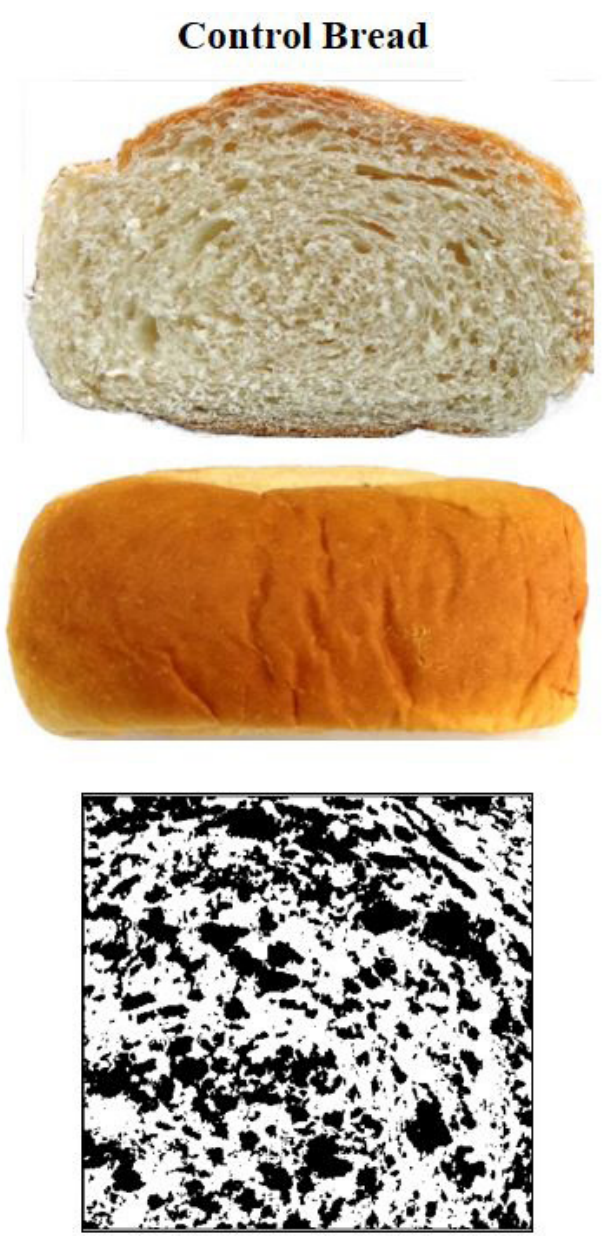

Andean blueberry Bread
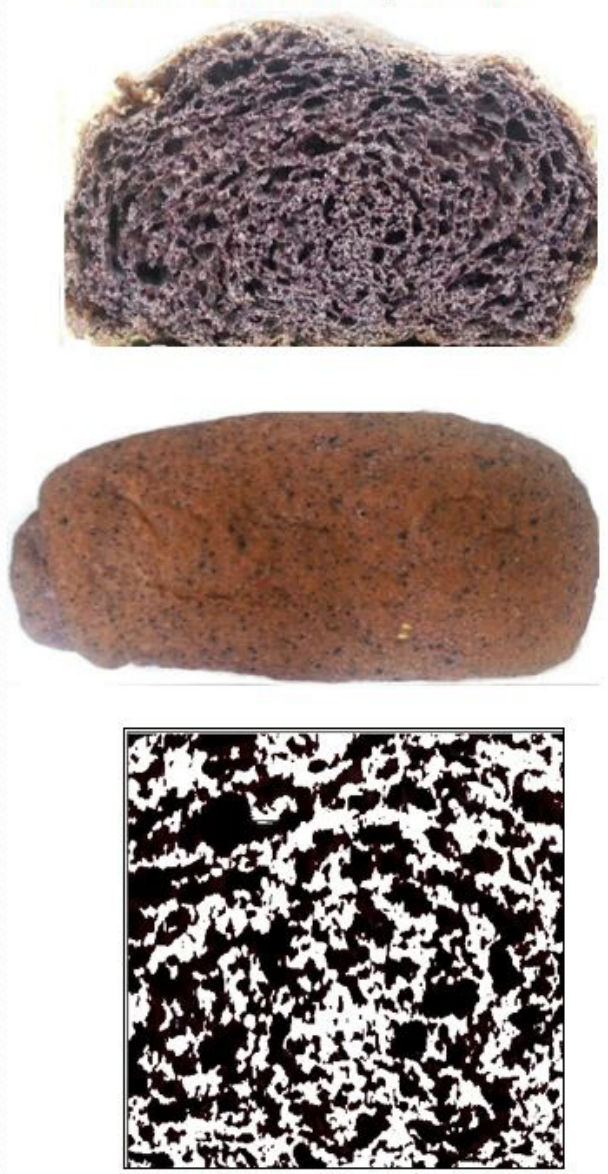

Figure 1. Color of crust and crumb in Control bread (left) and Andean blueberry bread (right).

the dough, among others (Park \& Morita, 2005), because the capacity of solids and fiber (Coba Santamaría et al., 2012) to retain water cause a decrease in the Aw of the product (Table 1).

\subsection{Crumb alveolate structure}

The structure of the crumb is mainly based on the number and size of alveoli. Consequently, the texture parameters are directly dependent on its characteristics (alveoli number, perimeter, circularity, area, air percentage) (Correa, 2012). The perimeter measurement refers to the constancy of the alveolar contour where, the lower this value, the more alveolar area regularity (Gan et al., 1995). According to the results, the AB bread crumb did not achieve correct alveolar stabilization, correlating in this way with the air fraction parameter. This parameter measures the percentage of air of the cross section of the alveoli with respect to the total area, as shown in Figure 1. The alveoli of the AB bread were characterized by size not being uniform, and because of this, the percentage of air retained is higher than in the control bread. These parameters depend on the matrix formed between gluten and starch (Correa, 2012). The difference in the number of alveoli with respect to the control was due to the low volume developed in the $\mathrm{AB}$ bread and its fragile structure to retain the gas, causing changes in the structure.
Circularity is a descriptor of the alveolus. Unlike the control, where small alveoli were determined because of the stability of cell walls, a symmetrical structure was not found in the $A B$ bread. The addition of $\mathrm{AB}$ pulp in the formulation would have also affected the circularity of the alveoli, reducing its size by $81.8 \%$ with respect to the control and affected the average alveolar area. This parameter relates to perimeter and its frequency in the crumb, decreasing in the $\mathrm{AB}$ bread up to $75 \%$ with respect to the control bread (Table 2) (Magdic et al., 2006).

\subsection{Texture Profile Analysis (TPA)}

Table 3 shows the results of the analysis of the TPA of the control bread and the AB bread. In all analyzed parameters (hardness, cohesiveness, elasticity, resilience and consistency) differences were found between the samples. The AB bread had a higher hardness value than the control bread. This could be reflected in a decrease in the quality perceived by the consumer when performing the chewing process (Correa, 2012), after comparison with the soft crumb offered by the control bread.

Cohesiveness is related to the rapid formation of the alimentary bolus with bread crumbs in chewing, the moisture of the product and the resistance of the alveolar walls. Elasticity is a value that describes the extent to which a baked product 
Table 2. Parameters of analysis of Control bread and Andean blueberry bread crumbs.

\begin{tabular}{ccc}
\hline Parameters & Control Bread & Andean blueberry Bread \\
\hline Alveoli Number & $567 \pm 87^{\mathrm{a}}$ & $192 \pm 64^{\mathrm{b}}$ \\
Perimeter $(\mathbf{c m})$ & $0.36 \pm 0.04^{\mathrm{b}}$ & $0.95 \pm 0.15^{\mathrm{a}}$ \\
Circularity $^{*}$ & $0.55 \pm 0.13^{\mathrm{a}}$ & $0.10 \pm 0.10^{\mathrm{b}}$ \\
${\text { Middle alveolar area }\left(\mathrm{cm}^{2}\right)}^{0}$ & $0.04 \pm 0.01^{\mathrm{a}}$ & $0.01 \pm 0.01^{\mathrm{b}}$ \\
\% Air & $42.6 \pm 1.3^{\mathrm{a}}$ & $52.5 \pm 11.8^{\mathrm{a}}$ \\
\hline
\end{tabular}

${ }^{*}$ Dimensional value. Averages with different letters in the same line show significant differences between the samples using the Tukey test $(\mathrm{p}<0.05)$.

Table 3. Texture profile analysis (TPA) of baked Control bread and Andean blueberry bread.

\begin{tabular}{ccc}
\hline Parameter & Control Bread & Andean blueberry Bread \\
\hline Hardness $(\mathbf{N})$ & $3.1 \pm 0.4^{\mathrm{b}}$ & $6.1 \pm 0.6^{\mathrm{a}}$ \\
Cohesiveness $^{\star}$ & $0.44 \pm 0.05^{\mathrm{a}}$ & $0.34 \pm 0.01^{\mathrm{b}}$ \\
Elasticity $^{*}$ & $0.89 \pm 0.04^{\mathrm{a}}$ & $0.80 \pm 0.05^{\mathrm{b}}$ \\
Resilience $^{\star}$ & $-3.2 \times 10^{-4} \pm 2.6 \times 10^{-4 \mathrm{a}}$ & $-2.2 \times 10^{-3} \pm 2.0 \times 10^{-3 \mathrm{~b}}$ \\
${\text { Consistency }\left(\mathrm{N}^{*} \mathbf{s}\right)}$ & $40.8 \pm 10.8^{\mathrm{b}}$ & $76.8 \pm 8.2^{\mathrm{a}}$ \\
\hline
\end{tabular}

${ }^{\star}$ Dimensional descriptive values. Averages with different letters in the same line show significant differences between the samples using the Tukey test $(\mathrm{p}<0.05)$.

can return to its original shape after being compressed between the teeth. Consumers associate an elastic crumb to fresh bread (Hernández, 2005). According to Correa (2012), the values of cohesiveness should be low to avoid an overexertion in chewiness. The control bread showed higher values of cohesiveness than $\mathrm{AB}$ bread, which also showed an elasticity of $10 \%$ lower than the controls. This difference could be related to the resistance of the alveolar walls produced by the addition of $\mathrm{AB}$ pulp in the formulation, which could affect the stability of the gluten network. Related to the resilience parameter, AB bread crumbs presented an $85 \%$ greater capacity to reincorporate to their original dimensions, and the consistency was $46.9 \%$ superior in $\mathrm{AB}$ bread. This could indicate that the addition of $\mathrm{AB}$ pulp in the formulation affected alveolar wall characteristics, considerably influencing the chewing process performed by the consumer (Silva et al., 2011).

\subsection{Antioxidant capacity prior to digestion}

The antioxidant capacity of fresh $\mathrm{AB}$, control bread and $\mathrm{AB}$ bread were determined (Table 4 ). The fruits presented a value of $731 \pm 9 \mathrm{mg}$ trolox equivalents $/ 100 \mathrm{~g}$ fresh tissue, similar to those reported by Vasco et al. (2008). AB is a fruit with a recognized antioxidant activity due to the high concentration of anthocyanins and vitamin C (Andrade, 2012). On the other hand, it is also known for its sensitivity to heat treatments (Gaviria et al., 2011). Studies on the loss of anthocyanins during the baking of bread enriched with cranberries have been carried out (Rodriguez et al., 2013).

Claudio et al. (2012) indicated that the antioxidant capacity of $\mathrm{AB}$ decreased approximately $50 \%$ after a treatment in conditions of $110^{\circ} \mathrm{C}$ for $30 \mathrm{~min}$. In this study $\mathrm{AB}$ bread presented a reduced antioxidant capacity compared to the fresh fruit (94.9\%), however,
Table 4. Antioxidant capacity of the products without digestion and during digestion stages.

\begin{tabular}{|c|c|c|c|c|}
\hline \multirow{2}{*}{\multicolumn{2}{|c|}{ Sample }} & \multicolumn{3}{|c|}{ Antioxidant Capacity ( $\mu \mathrm{M}$ trolox/g) } \\
\hline & & $\begin{array}{l}\text { Andean } \\
\text { blueberry }\end{array}$ & $\begin{array}{c}\text { Control } \\
\text { Bread }\end{array}$ & $\begin{array}{c}\text { Andean } \\
\text { blueberry } \\
\text { bread }\end{array}$ \\
\hline \multicolumn{2}{|c|}{ Product without digestion } & $731 \pm 9^{a}$ & $16.9 \pm 0.6^{\mathrm{e}}$ & $37.0 \pm 4.1^{\mathrm{c}}$ \\
\hline \multirow{4}{*}{$\begin{array}{l}\text { Digestion } \\
\text { Stage }\end{array}$} & Gastric & $43.9 \pm 1.8^{\mathrm{b}}$ & $\mathrm{N} / \mathrm{D}$ & $7.4 \pm 1.6^{\mathrm{fg}}$ \\
\hline & Duodenal & $21.6 \pm 2.1^{\mathrm{de}}$ & $4.4 \pm 0.8^{\mathrm{gh}}$ & $26.1 \pm 1.5^{\mathrm{d}}$ \\
\hline & $\begin{array}{l}\text { Bioaccessible } \\
\text { Fraction }\end{array}$ & $21.7 \pm 3.1^{\mathrm{de}}$ & $2.4 \pm 0.3^{\mathrm{gh}}$ & $10.6 \pm 0.8^{f}$ \\
\hline & $\begin{array}{c}\text { Bioaccessibility } \\
(\%)\end{array}$ & 2.8 & 14.3 & 28.6 \\
\hline
\end{tabular}

$\mathrm{N} / \mathrm{D}=$ Not detectable. Averages with different letters in the same row show significant differences between the samples using the Tukey test $(\mathrm{p}<0.05)$.

it maintains advantage against the control bread which had a 54.2\% lower antioxidant capacity than the AB bread.

Several studies highlight the use of anthocyanin-rich fruits as raw materials for the manufacturing of enriched products such as tortillas, baby food, bread and soft drinks, among others as a consumer alternative (Proaño, 2015; Shipp \& Abdel, 2010). However, the high content of antioxidant compounds in a meal does not necessarily indicate that the entire fraction present is absorbed and metabolized by the body. Therefore, it is necessary to determine the concentration of antioxidant compound and antioxidant capacity during the digestion process.

\subsection{Bioaccessibility of fresh Andean blueberry antioxidants}

$\mathrm{AB}$ was subjected to the in vitro digestion process, under conditions of $\mathrm{pH}$ and temperature similar to those of the gastrointestinal tract. As shown in Table 4, a significant difference was found in the antioxidant capacity in gastric digestion compared to duodenal digestion and bioaccessible fraction (content of antioxidant compounds after the dialysis process). The oral digestion stage (chewing) was not performed because no variation was found in the results between the initial food matrix and after the simulation of the chewing process (data not shown). In general, the published studies report results that exclude this stage (Gawlik-Dziki et al., 2014; Xuan et al., 2014).

An antioxidant activity of $43.9 \mu \mathrm{M}$ trolox/g fruit was found in gastric digestion, which decreased to 21.6 in the duodenal stage. After the dialysate process, a greater reduction in antioxidant capacity with respect to the duodenal stage was assumed; however, the values were stable $(21.7 \mu \mathrm{M}$ Trolox/g fruit). These results would be related to the rupture of the cell membranes and enzymatic inactivation during the gastric digestion stage (Claudio et al., 2012), as well as the physicochemical processes that would release the compounds with antioxidant activity from the structure of the tissue, therefore increasing its bioaccessibility. This behavior of the fresh $\mathrm{AB}$ fruit under simulated in vitro digestion conditions is similar to studies carried out by Carbonell-Capella et al. (2015), who determined that the salivary phase did not significantly affect the concentrations of components with antioxidant capacity in an exotic fruit beverage. However, these concentrations showed a decrease after passing through the gastric phase and 
an even greater decrease in digestion occurred with bile salts and pancreatin (duodenal phase). Similarly, Ting et al. (2014) determined that the polyphenols characteristic of water-soluble tea become unstable and oxidize under the drastic change of the gastric environment to the alkaline environment of the intestine, rapidly degrading.

\subsection{Bioaccessibility of bread antioxidants}

A meal digestion is influenced by certain parameters, characteristic of each organism by which it is metabolized and of the matrix containing it (Hur et al., 2011). The antioxidant fractions of the $\mathrm{AB}$ bread and the control bread obtained at each digestion stage (gastric, duodenal and bioaccessible portion) showed that in the simulation of the gastrointestinal process the anti-radical compounds of the $\mathrm{AB}$ bread presented greater bioaccessibility in vitro compared to the control bread (Table 4). Throughout the digestion stages, a higher antioxidant capacity was found in the $A B$ bread than in the control, due to the contribution of antioxidant compounds from the pulp in the formulation. For the $\mathrm{AB}$ bread in the gastric phase, a value of $7.4 \mu \mathrm{M}$ trolox/g bread was found, while in the control bread, no compounds with antioxidant activity were detected. In relation to the gastric stage, the fluid extract of the duodenal digestion presented an increase of 26.1 and $4.4 \mu \mathrm{M}$ trolox/g bread for the $\mathrm{AB}$ and control breads, respectively. This difference would be related to the kneading process in which the gluten is developed, forming an elastic dough that protects the compounds with antioxidant activity in the gastrointestinal tract (Cauvain, 2015; Claudio et al., 2012). In addition, in the duodenal stage, the $\mathrm{AB}$ bread demonstrated a greater release of antioxidant components than the control bread, with a difference of $83.1 \%$ between samples. This difference could be related to the fact that, in this phase, pancreatic enzymes and added bile salts first decompose the structures of emulsified lipids and then convert the tri and diglycerols into monoglycerols by displacing the molecules of the existing emulsions, finally transporting the remaining antioxidant compounds to the surface of the fluid (Hur et al., 2011).

After the dialysis process, the bioaccessible fraction of components with an antioxidant capacity decreased significantly with respect to the duodenal phase $(59.5 \%$ in the $\mathrm{AB}$ bread and $44.9 \%$ in the control bread). This could be related to the porosity of the dialysis membrane, which allows components to pass (according to molecular weight), limiting the absorption of polyphenols in the small intestine (Quiñones et al., 2012). Therefore, the bioaccessible fraction would be composed of substances with an antioxidant capacity of low molecular weight or compounds which have undergone modifications in the organization of their structure and nevertheless retained their antioxidant properties. Deprez et al. (2001) determined that high molecular weight polyphenols may not have been sufficiently hydrolyzed by enzymes in the gastrointestinal tract, making it difficult to pass through the epithelial membranes.

\section{Conclusions}

The addition of $\mathrm{AB}$ pulp in the bread formulation produced variation in the physicochemical characteristics of loaf bread. The specific volume was affected by the low fermentation rate, which is due to the acidic $\mathrm{pH}$ of the fruit. In terms of the results obtained by the TPA, a product with greater hardness and consistency and less sponginess was obtained in alveoli of smaller number, size and circularity. Nevertheless, there was more air retention in the crumb. Gastrointestinal conditions directly affected the antioxidant capacity of the $\mathrm{AB}$, producing a reduction of $96.9 \%$. On the other hand, the $A B$ bread initially presented a value of $37 \mu \mathrm{M}$ Trolox/g and, after the digestion process, a value of $10.6 \mu \mathrm{M}$ Trolox/g, corresponding to a percentage of bioaccessibility of $28.6 \%$. The global results indicate that the gluten network would protect the antioxidant compounds contributed by the $\mathrm{AB}$. It was possible to develop bread with healthier properties, due to the high antioxidant content of the $\mathrm{AB}$.

\section{References}

Aggett, P. J. (2010). Population reference intakes and micronutrient bioavailability: a European perspective. The American Journal of Clinical Nutrition, 91(5), 1433S-1437S. http://dx.doi.org/10.3945/ ajcn.2010.28674C. PMid:20200266.

Andrade, J. J. (2012). Estudio de la capacidad antioxidante total y contenido de compuestos antioxidantes en mortiño (Vaccinium floribundum) tratado con luz UV-C (Trabajo de Titulación). Universidad Tecnológica Equinoccial, Quito, Ecuador.

Arteaga Dalgo, M., Andrade Cuvi, M. J., \& Moreno Guerrero, C. (2012). Relación del desarrollo del color con el contenido de antocianinas y clorofila en diferentes grado de madurez de mortiño (Vaccinium floribundum). Revista Enfoque UTE, 5(2), 14-28. http://dx.doi. org/10.29019/enfoqueute.v5n2.37.

Association of Cereal Chemists International - AACCI. (2010). Approved methods of the American Association of Cereal Chemists International. St. Paul: AACCI.

Aura, A. M. (2005). In vitro digestion models for dietary phenolic compounds. VTT Biotechnology, 57, 1-107.

Bedolla, S., Dueñas, C., \& Trujillo, M. (2004). Tecnología de cereales: introducción a la tecnología de alimentos (2nd ed.). México: Limusa.

Bourne, M. (2002). Principles of objective texture measurement. In M. Bourne (Ed.), Food texture and viscosity (pp. 107-188). California: Academic Press. http://dx.doi.org/10.1016/B978-012119062-0/50004-8.

Carbonell-Capella, J. M., Buniowska, M., Esteve, M. J., \& Frígola, A. (2015). Effect of Stevia rebaudiana addition on bioaccessibility of bioactive compounds and antioxidant activity of beverages based on exotic fruits mixed with oat following simulated human digestion. Food Chemistry, 184, 122-130. http://dx.doi.org/10.1016/j. foodchem.2015.03.095. PMid:25872434.

Cauvain, S. (2015). Technology of breadmaking (3rd ed.). Witney: Springer.

Chaovanalikit, A., \& Wrolstad, R. E. (2004). Total anthocyanins and total phenolics of fresh and processed cherries and their antioxidant properties. Journal of Food Science, 69(1), 67-72. http://dx.doi. org/10.1111/j.1365-2621.2004.tb17858.x.

Claudio, R., Nájera, J., \& Santacruz, S. (2012). Evaluación de la actividad antioxidante de Vaccinium floribundum sometido a tratamiento térmico. Vitae, 19, S352-S354.

Coba Santamaría, P., Coronel, D., Verdugo, K., Paredes, M. F., Yugsi, E., \& Huachi, L. (2012). Estudio etnobotánico del mortiño (Vaccinium floribundum) como alimento ancestral y potencial alimento funcional. La Granja: Revista Ciencias de la Vida, 16(2), 5-13. http://dx.doi. org/10.17163/lgr.n16.2012.01.

Conesa, A., Pozo, J., Manjón, M. C., \& Galera, M. C. (2012). Tratamientos antipardeantes en berenjena mínimamente procesada. In Proceedings 
of the VII Congreso Español de Ingeniería de Alimentos. Ciudad Real, España: CESIA.

Correa, M. J. (2012). Efecto de celulosas modificadas y pectinas sobre la microestructura y atributos de calidad de la masa panaria (Ph.D. thesis). Universidad Nacional de La Plata, La Plata.

Delcour, J. A., \& Hoseney, R. (2010). Principles of cereal science and technology (3rd ed.). St. Paul: AACC Internacional. http://dx.doi. org/10.1094/9781891127632.

Deprez, S., Mila, I., Huneau, J. F., Tome, D., \& Scalbert, A. (2001). Transport of proanthocyanidin dimer, trimer, and polymer across monolayers of human intestinal epithelial Caco-2 cells. Antioxidants \& Redox Signaling, 3(6), 957-967. http://dx.doi. org/10.1089/152308601317203503. PMid:11813991.

Gan, Z., Ellis, P. R., \& Schofield, J. D. (1995). Gas cell stabilisation and gas retention in wheat bread dough. Journal of Cereal Science, 21(3), 215-230. http://dx.doi.org/10.1006/jcrs.1995.0025.

Gaviria, C., Ochoa, C., Sánchez, N., Medina, C., Lobo, M., Galeano, P., Mosquera, A., Tamayo, A., Lopera, Y., \& Rojano, B. (2011). Propiedades antioxidantes de los frutos de agraz o mortiño (Vaccinium meridionale Swartz). In G. Ligarreto (Ed.), Perspectivas de cultivo de agraz o mortiño (Vaccinium meridionale Swartz) en la zona altoandina de Colombia (pp. 93-112). Bogotá: Gente Nueva.

Gawlik-Dziki, U., Świeca, M., Dziki, D., Sęczyk, Ł., Złotek, U., Różyło, R., Kaszuba, K., Ryszawy, D., \& Czyż, J. (2014). Anticancer and antioxidant activity of bread enriched with broccoli sprouts. BioMed Research International, 2014, 608053. PMid:25050366.

Gião, M. S., Gomes, S., Madureira, A. R., Faria, A., Pestana, D., Calhau, C., Pintado, M. E., Azevedo, I., \& Malcata, F. X. (2012). Effect of in vitro digestion upon the antioxidant capacity of aqueous extracts of Agrimonia eupatoria, Rubus idaeus, Salvia sp. and Satureja montana. Food Chemistry, 131(3), 761-767. http://dx.doi.org/10.1016/j. foodchem.2011.09.030.

Gutiérrez, A., Ledesma, L., Isabel, G. G., \& Grajales, O. (2007). Capacidad antioxidante total en alimentos convencionales y regionales de Chiapas. Revista Cubana de Salud Pública, 33, 1-8.

Hernández, E. (2005). Evaluación sensorial (1st ed.). Bogotá: UNAD.

Hur, S. J., Lim, B. O., Decker, E. A., \& McClements, D. J. (2011). In vitro human digestion models for food applications. Food Chemistry, 125(1), 1-12. http://dx.doi.org/10.1016/j.foodchem.2010.08.036.

Jadán, C. A., Devesa, V., Vélez, D., \& Gavara, R. (2013). Evaluación de las etapas y los factores que influyen en la solubilización de mercurio y selenio durante la digestión gastrointestinal de productos pesqueros (Ph.D. thesis). Universidad Politécnica de Valencia, Valencia.

Magdic, D., Horvat, D., Drezner, G., Jurkovic, Z., \& Simic, G. (2006). Image analysis of bread crumb structure in relation to gluten strength of wheat. Hrcak, 12(1), 1-6.

Park, S. H., \& Morita, N. (2005). Dough and breadmaking properties of wheat flour substituted by $10 \%$ with germinated quinoa flour. Food Science \& Technology International, 11(6), 471-476. http:// dx.doi.org/10.1177/1082013205060766.

Pokorn, J., Yanishlieva, N., \& Gordon, M. (2001). Antioxidantes de los alimentos, aplicaciones prácticas (1st ed.). Zaragoza: Acribia.

Proaño, C. A. (2015). Elaboración de refresco de mortiño (Vaccinium floribundum) (Ph.D. thesis). Universidad Tecnológica Equinoccial, Quito.
Quiñones, M., Miguel, M., \& Aleixandre, A. (2012). Los polifenoles, compuestos de origen natural con efectos saludables sobre el sistema cardiovascular. Nutrición Hospitalaria, 27(1), 76-89. PMid:22566306.

Quintanar, M. A., \& Calderón, J. V. (2009). La capacidad antioxidante total: bases y aplicaciones. Revista de Educación Bioquímica, 28, 89-101.

Re, R., Pellegrini, N., Proteggente, A., Pannala, A., Yang, M., \& RiceEvans, C. (1999). Antioxidant activity applying and improved ABTS radical cation decolorization assay. Free Radical Biology \& Medicine, 26(9-10), 1231-1237. http://dx.doi.org/10.1016/S08915849(98)00315-3. PMid:10381194.

Rodriguez, A., Cifuentes, T. W., \& Spencer, J. P. (2013). Impact of cooking, proving, and baking on the polyphenol content of wild blueberry. Journal of Agricultural and Food Chemistry, 6, 3979-3986.

Rollán, G., Gerez, C. L., Dallagnol, M. A., Torino, M. I., \& Font, G. (2010). Update in bread fermentation by lactic acid bacteria. In A. Mendez-Villas (Ed.), Current research, technology education topics in applied microbiology and microbial biotechnology (pp. 1168-1174). Badajoz: Formatex.

Rupasinghe, H. P., Wang, L., Gwendolyn, M. H., \& Pitts, N. L. (2008). Effect of baking on dietary fibre and phenolics of muffins incorporated with apple skin powder. Food Chemistry, 107, 1217-1224.

Sánchez, M. T. (2002) Memoria descriptiva de producto congelado baguette. Córdoba: Universidad de Córdoba. Retrieved from http://www.uco. es/dptos/bromatologia/tecnologia/bib-virtual/bajada/mempan.pdf

Shipp, J., \& Abdel, E. S. (2010). Food applications and physiological effects of anthocyanins as functional food ingredients. Journal of Food Science, 4, 7-22.

Silva, J. T., Ribeiro, M., Paula, C. D., Leite, D., \& Paes, J. B. (2011). Caracterização físico-química e sensorial de pão de sal enriquecido com farinha integral de linhaça. Boletim do Centro de Pesquisa e Processamento de Alimentos, 29(1), 83-96.

Sui, X., Yap, P. Y., \& Zhou, W. (2015). Anthocyanins during baking: Their degradation kinetics and impacts on color and antioxidant capacity of bread. Food and Bioprocess Technology, 8(5), 983-994. http://dx.doi.org/10.1007/s11947-014-1464-X.

Ting, Y., Jiang, Y., Ho, C.-T., \& Huang, Q. (2014). Common delivery systems for enhancing in vivo bioavailability and biological efficacy of nutraceuticals. Journal of Functional Foods, 7, 112-128. http:// dx.doi.org/10.1016/j.jff.2013.12.010.

Torres, S. (2011). Bioaccesibilidad de arsénico y mercurio en alimentos con potencial riesgo toxicológico (Ph.D. thesis). Universidad de Valencia, Valencia.

Vasco, C., Ruales, J., \& Kamal-Eldin, A. (2008). Total phenolic compounds and antioxidant capacities of major fruits from Ecuador. Food Chemistry, 111(4), 816-823. http://dx.doi.org/10.1016/j.foodchem.2008.04.054.

Versantvoort, C., Kamp, E., \& Rompelberg, C. (2004). Development and applicability of an in vitro digestion model in assessing the bioaccessibility of contaminants from food. The Netherlands: RIVM.

Westland, S. (2012) Colour physics (1st ed.). Bawtry: Magus Publishing. Retrieved from https://www.amazon.co.uk/d/Books/Colour-PhysicsFrequently-Asked-Questions-Stephen-Westland/147010153X

Xuan, L., Linwei, L., Wasila, H., Zhongmei, G., Tian, Y., \& Beita, Z. (2014). Variation of polyphenols composition and bioactivities of pomegranate wines along in vitro digestion process. Journal of Food and Nutrition Research, 2(11), 839-845. http://dx.doi.org/10.12691/ jfnr-2-11-13. 